KREATIF : Jurnal Ilmiah Prodi Manajemen Universitas Pamulang, Vol. 8, No.2, Desember 2020

\section{KREATIF Jurnal IImiah}

@ Prodi Manajemen Fakultas Ekonomi Universitas Pamulang ISSN : 2339 - 0689, E-ISSN : 2406-8616

J. KREATIF, Vol. 8 No.2, Desember 2020 (Halaman 15-28)

Tersedia Online di :http://openjournal.unpam.ac.id/index.php/kreatif

\title{
PENGARUH KOMPENSASI DAN MOTIVASI KERJA TERHADAP KINERJA GURU PNS SD NEGERI Kecamatan Pamulang Kota Tangerang Selatan
}

\author{
Devi Putri Isnaeni \\ Program Studi Manajemen Fakultas Ekonomi Universitas Pamulang \\ email: dosen02285@unpam.ac.id
}

\begin{abstract}
ABSTRAK
Penelitin ini bertujan untuk mengtahui pengarh kompnsasi terhadp kinrja guru secara parsial, mengetahi pengarh motivai kerja terhadap kineja guru secara parsial, dan mngetahui pengaruh kompensasi dan motivsi kerja terhadp kinrja guru secara simultan atau bersama-sama.

Metode penelitian ini menggunakn kuantitatif deskripif. Penelitian ini mengambil populasi seluruh guru PNS Sekolah Dasar Negeri di Kecamatan Pamulang Kota Tangerang Selatan yang berjumlah 331, sedangkan penentuan sampel menggunakan rumus slovin yang diperoleh 181 responden. Variabel penelitian terdiri dari variabel independen atau variabel bebas (X) yaitu kompensasi (X1) dan motivasi kerja (X2), sedangkan variabel dependen atau variabel terikat (Y) yaitu kinerja guru. Data yang diperoleh dari penelitian ini akan dianalisis dengan menggunakan metode statistik dengan program SPSS versi 23.

Hasil penelitian menunjukkan dalam uji t (parsial) bahwa kompensasi secara signifikan mempengaruhi kinerja guru dengan nilai sig $0,000<0,05$ dan nilai $\mathrm{t}$ hitung 4,760, dan motivasi kerja secara signifikan mempengaruhi kinerja guru dengan nilai sig $0,000<$ 0,05 dan nilai $t$ hitung 7,430 . Hasil uji $\mathrm{F}$ (simultan) bahwa kompensasi dan motivasi kerja secara signifikan mempengaruhi kinerja guru dengan nilai sig $0,000<0,05$ dan nilai $\mathrm{F}$ hitung 31,452. Jadi, dapat disimpulkan bahwa kompensasi dan motivasi kerja mempengaruhi kinerja guru baik secara parsial maupun simultan.
\end{abstract}

Kata kunci : Kompensasi, Motivasi Kerja, Kinerja Guru

\section{ABSTRACT}

The aims of this study is to see the effect of compensation on teacher performance partially influence work motivation on teacher performance, and the compensation response and work motivation to teacher performance simultaneously or collectively.

The method used in this study is descriptive quantitative. This study took a population of all State Elementary School PNS teachers in Pamulang District, South Tangerang City which got 331, while determining the sample using the Slovin formula obtained by 181 respondents. The research variable of the independent variable or independent variable $(X)$ is compensation $(X 1)$ and work motivation $(X 2)$, while the dependent variable or dependent variable $(Y)$ is teacher performance. The data obtained from this study will be analyzed using statistical methods with the SPSS program version 23. The results showed in the $t$ test (partial) that compensation significantly affected teacher performance with a sig value of $0.000<0.05$ and a $t$ value of 4.760 , and work motivation significantly affected teacher performance with a sig value of $0.000<0.05$ and 
KREATIF : Jurnal Ilmiah Prodi Manajemen Universitas Pamulang, Vol. 8, No.2, Desember 2020

a value of $t$ count of 7.430. . The results of the $F$ test (simultaneous) show that compensation and work motivation significantly affect teacher performance with a sig value of $0.000<0.05$ and an $F$ value of 31.452. So, it can be ignored that compensation and work motivation affect teacher performance either partially or simultaneously.

Keywords: Compensation, Work Motivation, Teacher Performance

\section{PENDAHULUAN}

\section{A. Latar Belakang MasalaH}

Pendidkan merupakn salh satu faktor terpentng untuk membangn suau negara, dngan penddikan setiap manusia mampu untuk mengmbangkan potnsi yang ada pada dirinya agar menjadi sumber daya yang berkualitas, sesuai dengan apa yang tertera pada UndangUndang SISDIKNAS No. 20 Tahun 2003 pasal 1 yang menjelaskan bahwa "pendidikan adalah usaha sadar dan terencana untuk mewujudkan suasana belajar dan proses pembelajaran agar peserta didik secara aktif mengembangkan potensi dirinya untuk memiliki kekuatan spiritual, keagamaan, pengendalian diri, kepribadian, kecerdasan, akhlak mulia, serta keterampilan yang diperlukan dirinya, masyarakat, bangsa dan negara". Pendidkan dislenggarakan dngan memberdayakan semua komponen masyarakat melalui peran serta dalam penyelenggaraan dan pengendalin mutu layann pendidian, Elfachmi (2016: 124).

Jika kita perhatikan lebih dalam pada proses pendidikan, terdapat tahapan pada tingkat pendidikan tahapan pertama tahap awal pendidikan yang kita sebut sekolah dasar. Para peserta didik mulai mengalami proses pendidikan dan pembelajaran lebih berkembang pada tahapan ini. Penyelenggaraan pendidikan dasar tidak lain adalah untuk membekali dasar pengetahuan, sikap serta keterampilan pada anak didik agar dapat meningkatkan kualitas yang ada pada diri anak didik.

Sesuai dengn Undang-Undang tentang Sistem Pndidikan Nasional, pendidikn merupakn hak dari semua individ. Undag-Undag Nomor 20 Tahun 2003 Pasal 1 ayat 1 tentang Sistem Pendidikan Nasional menyatkan bahw: "Pendidikan nasional berfungsi mengembangkan kemampuan dan membentuk watak serta peradaban bangsa yang bermartabat dalam rangka mencerdaskan kehidupan bangsa, bertujuan untuk berkembangkan potensi siswa agar menjadi manusia yang beriman, bertaqwa kepada Tuhan Yang Maha Esa, berakhlaq mulia, sehat, berilmu, cakap, kreatif, mandiri dan menjadi warga negara yang demokratis serta bertanggung jawab". Untuk mencapai tujuan tersebut dapat melibatkan peran seorang tenaga kependidikan yang merupakan salah satu dari bagian pemerintah, adapun status tenaga kependidikan tersebut salah satunya berstatus Pegawai Negeri Sipil (PNS) yang memiliki tugas pokok dan fungsi yang cukup berat dalam mendidik peserta didik, dalam hal tersebut PNS berhak memperoleh gaji dan kesejahteraan lainnya atas jasa yang telah diberikan dalam pendidikan.

Adapun tenaga kependidikan yang dimaksud adalah guru, guru merupakn pekerjan profesionl sehingg tepat untk dikatakan sebgai suatu profsi. Sebagi suatu prfesi pengembangn kemampuan dan peningkatn kompetnsi merupakn hal penting yang dapat memberikn kontribsi signifikn bagi peningkatan kualits pendidikan dan pembelajarn di sekolah. Sehinga guru merupakan elemen kunci dalam sistem pendidikan, khususnya disekolah. Semua kompone lain, mulai dari kurikulm, sarana prasaran, biaya dan sebagaiya tidak akan bnyak berarti apabila cra pembelajarn guru terhadp peserta didik tidak berkualits. 
KREATIF : Jurnal Ilmiah Prodi Manajemen Universitas Pamulang, Vol. 8, No.2, Desember 2020

Dalam memaksimalkan peran guru, kebutuhan guru menjadi hal penting bagi pemerintah, karena tanggung jawab guru sekolah dasar terhadap peserta didik cukup berat, untuk menjamin kesejahteraan guru diperlukan suatu sistem yang dapat menjamin keadilan dan kepastian. Kesejahteraan guru dapat berbentuk finansial maupun non finansial, terpenuhinya kesejahteraan guru cukup berpengaruh terhadap kinerja dalam pelaksanaan tugasnya.

Agar kinerja guru dapat diperoleh secara optimal maka penghasilan guru pun perlu diperhatikan dengan pemberian kompensasi. Menurut Ivancevich (1995) dalam Kadarisman (2012:6), "kompensasi adalah fungsi Human Resource Management (HRM) yang berhubungan dengan setiap jenis reward yang diterima individu sebagai balasan atas pelaksanaan tugas-tugas organisasi. Pegawai menukarkan tenaganya untuk mendapatkan reward finansial maupun nonfinansial. Sebagai penghargaan atas penyerahan dan pemberian segenap hasil kerja atau performance pegawai kepada organisasi, maka organisasi memberikan balas jasa, imbalan jasa, penghargaan, penghasilan, kompensasi atau reward." Kadarisman (2012:6). Ditinjau dari sisi pandang pendidikan, pemberian imbalan jasa atau penghasilan akan selalu dikaitkan dengan kuantitas dan kualitas yang dilakukan oleh guru terhadap peserta didik.

Dalam hal kompensasi guru PNS di Sekolah Dasar Negeri pada Kecamatan Pamulang mendapatkan kompensasi berupa gaji pokok yang sesuai dengan pangkat, golongan dan masa kerjanya. Bagi guru PNS gaji yang diterima sudah cukup membantu untuk keperluan sehari-hari terlebih dengan adanya sertifikasi, tunjangan, tambahan penghasilan PNS (TPP) dan ada pula pemberian kesra dari pihak sekolah, namun pada sistem penggajiannya belum memuaskan pihak guru dikarenakan sering terjadinya keterlambatan dalam penerimaan kompensasi. Melalui wawancara dengan beberapa guru, diketahui bahwa minimnya kesra (kesejahteraan rakyat/guru) yang diberikan oleh pihak sekolah, sering terjadinya keterlambatan dalam penerimaan tambahan penghasilan PNS, dan tidak adanya imbalan untuk guru yang kelebihan jam kerja.

"Dalam melaksanakan perannya sebagai guru, pada dasarnya guru telah dibekali dengan kemampuan professional, yang hanya mungkin dilaksanakan secara baik apabila fasilitas untuk keperluan tersebut tersedia dan dapat digunakan. Fasilitas tersebut terutama berkenaan dengan tingkat kesejahteraan guru, yang hanya mampu mendorong dan meningkatkan pengabdian, dedikasi dan loyalitas yang tinggi dalam melaksanakan tugas dan tanggung jawab profesionalnya sehari-hari” Syaiful Sagala (99:2010).

Dengan adanya fasilitas yang memadai kegiatan belajar mengajar dapat berjalan dengan lancar sehingga guru dapat melaksanakan tugasnya dengan maksimal. Melalui observasi yang dilakukan oleh peneliti, tidak semua sekolah di Kota Tangerang Selatan mempunyai fasilitas untuk para guru, ada sekolah yang tidak mempunyai ruang guru, dikarenakan kurangnya ruang kelas untuk kegiatan belajar mengajar sehingga ruang yang seharusnya menjadi ruang guru kini dijadikan ruang kelas, dengan keadaan yang seperti ini membuat guru merasa kurang nyaman karena tidak memiliki ruangan pribadi, hal tersebut menunjukkan adanya ketidaknyamanan yang dirasakan oleh guru.

Menurut Sahertien (2010:1) menyatakan bahwa "dalam usaha meningkatkan kualitas sumber daya pendidikan, guru merupakan komponen sumber daya manusia yang harus dibina dan dikembangkan terus-menerus". Hal ini diperkuat oleh pendapat Mulyasa (2013:5) menyatakan bahwa "komponen paling menentukan dalam sistem pendidikan adalah guru, sehingga harus mendapat perhatian yang utama. Seorang guru harus dapat 
KREATIF : Jurnal Ilmiah Prodi Manajemen Universitas Pamulang, Vol. 8, No.2, Desember 2020

menyesuaikan diri dengan adanya perkembangan ilmu pengetahuan dan teknologi yang cepat, karena guru harus menjalankan fungsinya secara profesional".

Perkembangan teknologi yang semakin berkembang diharuskan kepada para guru untuk dapat mengikuti perkembangan saat ini, seperti guru harus mampu untuk dapat menggunakan komputer, namun realitasnya terdapat beberapa guru yang belum mampu untuk dapat menyesuaikan dirinya untuk menyelesaikan pekerjaannya menggunakan komputer maupun laptop, sehingga kinerja guru menjadi kurang efektif dan efisien.

Kinerja guru yang efektif dan efisien akan menghasilkan sumber daya manusia yang berkualitas, oleh karena itu kinerja guru dalam proses pembelajaran perlu ditingkatkan sehingga kegiatan yang ada akan menjadi lebih laik.

Menurut Gibson, et al dalam Supardi (2013: 51) "salah satu variabel yang mempengaruhi aspek kinerja guru adalah variabel psikologis, yang meliputi: persepsi, sikap, kepribadian, belajar, motivasi, kepuasan kerja, iklam kerja. Sama halnya pendapat Gibson dalam Kompri (2014:162) menyatakan bahwa kinerja manusia atau yang sering dikenal dengan human performance ditentukan oleh kemampuan (ability) dan motivasi (motivation)".

Menurut Edy Sutrisno (2009:109) menyatakan bahwa "motivasi adalah suatu faktor yang mendorong seseorang untuk melakukan suatu aktivitas tertentu, faktor pendorong dari seseorang untuk melakukan suatu aktivitas tertentu pada umumnya adalah kebutuhan serta keinginan orang tersebut. Berdasarkan hasil wawancara peneliti dengan guru ditemukan bahwa kurangnya perhargaan yang diberikan sekolah kepada guru berprestasi sehingga motivasi guru berkurang yang menyebabkan menurunnya kinerja guru".

"Pada Undang-undang RI Nomor 20 Tahun 2003 tentang Sistem Pendidikan Nasional pada Pasal 40, ayat 2 yang berisi Pendidik dan tenaga kependidikan berkewajiban:

1. Menciptakan suasana pendidikan yang bermakna, menyenangkan, kreatif, dinamis, dan dialogis;

2. Mempunyai komitmen secara profesional untuk meningkatkan mutu pendidikan;

3. Memberi teladan dan menjaga nama baik lembaga, profesi, dan kedudukan sesuai dengan kepercayaan yang diberikan kepadanya".

Menurut Mulyani dan Johar (1999: 262) menjabarkan "keterampilan mengajar, yaitu keterampilan menjelaskan, keterampilan bertanya, keterampilan menggunakan variasi, keterampilan memberikan penguatan keterampilan membuka dan menutup pelajaran, keterampilan mengajar kelompok kecil dan perorangan, keterampilan mengelola kelas, serta keterampilan membimbing diskusi kelompok kecil".

Berdasarkan observasi peneliti pada Sekolah Dasar Negeri di Kecamatan Pamulang ditemukan fenomena metode pembelajaran guru yaitu masih banyak guru yang menggunakan metode ceramah dan tanya jawab dengan peserta didik, sehingga menciptakan pembelajaran yang kurang menyenangkan dan membosankan bagi siswa sehingga kurangya minat siswa dalam belajar di sekolah.

Apabila masalah metode pembelajaran ini terus dipertahankan oleh guru dan dibiarkan oleh kepala sekolah, maka minat belajar siswa akan tetap rendah dan kualitas proses pembelajaran akan tetap rendah, sehingga sulit untuk menggapai kualitas pendidikan yang diharapkan pendidikan. Berdasarkan uraian di atas, penulis tertarik untuk melakukan penelitian dengan judul "Pengaruh Kompensasi Dan Motivasi Kerja 
KREATIF : Jurnal Ilmiah Prodi Manajemen Universitas Pamulang, Vol. 8, No.2, Desember 2020

\section{Terhadap Kinerja Guru Pns Sd Negeri Kecamatan Pamulang Kota Tangerang} Selatan"

\section{B. Tujuan Penelitian}

Berdasarkan latar belakang masalah yang telah dikemukakan di atas maka dapat dirumuskan tujuan penelitian sebagai berikut :

1. Untuk mengetahui seberapa besar pengaruh kompensasi terhadap kinerja guru PNS SD Negeri Kecamatan Pamulang.

2. Untuk mengetahui seberapa besar pengaruh motivasi kerja terhadap kinerja guru PNS SD Negeri Kecamatan Pamulang.

3. Untuk mengetahui seberapa besar pengaruh kompensasi dan motivasi kerja terhadap kinerja guru PNS SD Negeri Kecamatan Pamulang.

\section{KAJIAN PUSTAKA}

\section{A. Kompensasi}

Pada dasarnya manusia bekerja ingin memperoleh uang untuk memenuhi kebutuhan hidupnya. Untuk itulah karyawan bekerja keras dan menunjukkan loyalitasnya kepada perusahaan dan karena itulah perusahaan memberikan penghargaan terhadap preatasi kerja karyawan yaitu dengan memberikan kompensasi.

Menurut M. Yani (2012: 139), "kompensasi adalah bentuk pembayaran (langsung atau tidak langsung) dalam bentuk manfaat dan insentif untuk memotivasi karyawan agar produktivitas kerja semakin meningkat/tinggi. Kompensasi dalam bentuk finansial langsung seperti gaji, upah, komisi dan bonus. Dan kompensasi tidak langsung seperti asuransi, bantuan sosial, uang cuti, uang pensiun, pendidikan dan lain-lain”.

Edy Sutrisno (2009: 10) berpendapat "kompensasi merupakan pemberian balas jasa langsung berupa uang atau barang kepada pegawai sebagai imbalan jasa yang diberikan kepada organisasi. Prinsip kompensasi adalah adil dan layak. Adil diartikan sesuai dengan prestasi kerja, sedangkan layak diartikan dapat memenuhi kebutuhan primer".

Sebagaimana yang diungkapkan Panggabean dalam (Edy Sutrisno, 2009: 181). "Kompensasi dapat didefinisikan sebagai setiap bentuk penghargaan yang diberikan kepada karyawan sebagai balas jasa atas kontribusi yang mereka berikan kepada organisasi".

Sedangkan menurut Umar (2005: 16). "Salah satu cara manajemen untuk meningkatkan prestasi kerja, motivasi, dan kepuasan kerja para karyawan adalah melalui kompensasi. Kompensasi dapat didefinisikan sebagai sesuatu yang diterima karyawan sebagai balas jasa untuk kerja mereka. Sebelum kompensasi diberikan, terlebih dahulu dilakukan proses kompensasi. Yaitu suatu jaringan sebagai sub-proses untuk memberikan balas jasa kepada karyawan untuk pelaksanaan pekerjaan dan untuk memotivasi mereka agar mencapai tingkat prestasi yang diinginkan".

Menurut Thomson dalam (Sedarmayanti, 2013:26) "mengemukakan bahwa kompensasi adalah faktor penting yang mempengaruhi bagaimana dan mengapa orangorang bekerja pada suatu organisasi dan bukan pada organisasi lainnya".

Hasibuan (2012:118) mengemukakan bahwa kompensasi adalah semua "pendapatan yang berbentuk uang, barang langsung atau tidak langsung yang diterima karyawan sebagai imbalan atas jasa yang diberikan kepada perusahaan”. 
KREATIF : Jurnal Ilmiah Prodi Manajemen Universitas Pamulang, Vol. 8, No.2, Desember 2020

Menurut Samsudin (2006:187) "kompensasi mengandung arti yang lebih luas dari pada upah atau gaji. Upah atau gaji lebih menekankan pada balas jasa yang bersifat finansial, sedangkan kompensasi mencakup balas jasa finansial maupun non-finansial".

Menurut Ivancevich dalam Kadarisman (2012:6), "kompensasi adalah fungsi Human Resource Management (HRM) yang berhubungan dengan setiap jenis reward yang diterima individu sebagai balasan atas pelaksanaan tugas-tugas organisasi. Pegawai menukarkan tenaganya untuk mendapatkan reward finansial maupun non finansial".

Berdasarkan penjelasan di atas, dapat disimpulkan bahwa kompensasi merupakan suatu pemberian imbalan yang diberikan kepada pegawai secara langsung maupun tidak langsung yang sesuai dengan pekerjaannya.

\section{B. Motivasi Kerja}

Menurut Sardiman (2011: 73) "Motivasi berpangkal dari kata "motif" yang diartikan daya penggerakan yang ada di dalam diri seseorang untuk melakukan aktivitas-aktivitas tertentu demi tercapainya tujuan". Sementara itu, Malayu S.P Hasibuan (2003: 95) menyatakan bahwa "Motivasi adalah pemberian daya penggerak yang menciptakan kegairahan kerja seseorang, agar mereka mau bekerjasama, bekerja efektif dan terintegrasi dengan segala daya upayanya untuk mencapai kepuasan."

"Motivasi merupakan proses mempengaruhi atau mendorong dari luar terhadap seseorang atau kelompok kerja agar mereka mau melaksanakan sesuatu yang telah ditetapkan. Sadili Samsudin (2006:281-282)".

Menurut Gray (Arif Yusuf Hamali, 2016:130) mendefinisikan "motivasi sebagai hasil sejumlah proses yang bersifat internal atau eksternal bagi seorang individu, yang menyebabkan timbulnya sikap antusiasme dan persistence dalam hal melaksanakan kegiatan-kegiatan tertentu". Sedangkan menurut Hamzah B. Uno (2008: 1) "menyatakan bahwa motivasi sebagai kekuatan, baik dari dalam maupun dari luar yang mendorong seseorang untuk mencapai tujuan tertentu yang telah ditetapkan sebelumnya".

Menurut Anwar Prabu Mangkunegara (2013:93) menyatakan bahwa "motivasi kerja sebagai suatu kecenderungan untuk beraktivitas dan dimulai dorongan dalam diri sendiri (drive) dan diakhiri dengan penyesuaian diri. Penyesuaian diri dikatakan untuk memuaskan motif.

Berdasarkan penjelasan di atas, dapat disimpulkan bahwa motivasi kerja adalah dorongan dari dalam maupun dari luar terhadap seseorang ataupun kelompok kerja agar mau melaksanakan tugasnya untuk mencapai tujuan tertentu."

\section{Kinerja Guru}

Kinerja merupakan hasil yang dicapai oleh seseorang atau kelompok orang yang melakukan pekerjaan dan dievaluasi oleh pihak tertentu.

Menurut Arif Yusuf Hamali (2016: 98) istilah "performance sering diindonesiakan sebagai performa, atau dikenal juga dengan istilah kinerja. Kinerja adalah keluaran yang dihasilkan oleh fungsi-fungsi atau indikator-indikator suatu pekerjaan atau suatu profesi dalam waktu tertentu. Pekerjaan adalah aktivitas menyelesaikan sesuatu atau membuat sesuatu yang hanya memerlukan tenaga dan keterampilan tertentu seperti yang dilakukan oleh pekerja kasar atau blue collar worker. Profesi adalah pekerjaan yang untuk menyelesaikannya memerlukan penguasaan dan menerapkan teori ilmu pengetahuan yang dilakukan oleh profesional atau white coller worker."

Istilah kerja juga dapat digunakan untuk menunjukkan keluaran perusahaan, alat, fungsi-fungsi manajemen (produksi, pemasaran, keuangan), atau keluaran seorang 
KREATIF : Jurnal Ilmiah Prodi Manajemen Universitas Pamulang, Vol. 8, No.2, Desember 2020

karyawan. Menurut Mangkunegara (2013:67) "istilah kinerja berasal dari kata job performance atau actual performance (prestasi kerja atau prestasi sesungguhnya yang dicapai oleh seseorang). Pengertian kinerja (prestasi kerja) adalah hasil karya secara kualitas yang dicapai oleh seseorang pegawai dalam melaksanakan tugasnya sesuai dengan tanggung jawab yang diberikan kepadanya. Mangkunegara (2009:67) kinerja adalah hasil kerja secara kualitas dan kuantitas yang dicapai oleh seorang pegawai dalam melaksanakan tugasnya sesuai dengan tanggung jawab yang diberikan kepadanya."

Menurut Suwanto (2011:196). Kinerja merupakan "performance atau unjuk kerja dan kinerja dapat pula diartikan sebagai prestasi kerja atau pelaksanaan kerja atau hasil unjuk kerja". "Sedangakn menurut Sedarmayanti (2011:260) mengungkapkan bahwa kinerja merupakan terjemahan dari performance yang berarti hasil kerja seorang pekerja, sebuah proses manajemen atau suatu organisasi secara keseluruhan, dimana hasil kerja tersebut harus dapat ditunjukkan buktinya secara konkrit dan dapat diukur (dibandingkan dengan standar yang telah ditentuka)".

Menurut A. Tabrani Rusyan dkk (2000:17), "kinerja guru adalah melaksanakan proses pembelajaran baik dilakukan di dalam kelas maupun di luar kelas di samping mengerjakan kegiatan-kegiatan lainnya, seperti mengerjakan administrasi sekolah dan administrasi pembelajaran, melaksanakan bimbingan dan layanan pada para siswa, serta melaksanakan penilaian".

Menurut Malayu S.P Hasibuan (2001: 94) kinerja guru adalah "suatu hasil kerja yang dicapai seseorang guru dalam melaksanakan tugas-tugas yang dibebankan kepadanya yang didasarkan atas kecakapan, pengalaman, dan kesungguhan serta waktu. Kinerja guru dapat dilihat saat dia melaksanakan interaksi belajar-mengajar dikelas termasuk persiapannya baik dalam bentuk program semester maupun persiapan mengajar."

\section{METODOLOGI PENELITIAN}

\section{A. Tempat dan Waktu Penelitian}

Untuk mendapatkan data yang diperlukan dalam penyusunan tesis ini, penulis melakukan penelitian di Sekolah Dasar Negeri Kecamatan Pamulang, Kota Tangerang Selatan, Banten,

Penelitian ini dilakukan selama 9 bulan, mulai dari bulan Desember 2016 sampai dengan bulan Agustus 2017. Penelitian dilakukan secara bertahap yang dimulai dari pra survey penelitian, pengajuan judul penelitian, mengajukan kajian pustaka yang sesuai dengan variabel yang dipilih, menyusun proposal, mengadakan seminar proposal, perbaikan proposal, menyebarkan kuesioner, analisis dan pengolahan data, penulisan laporan penelitian, konsultasi ke Dosen Pembimbing, perbaikan laporan, dan ujian Tesis.

\section{B. Metode Penelitian}

Metode Penelitian adalah suatu teknik atau cara mencari, memperoleh, mengumpulkan dan mencatat data, baik data primer maupun data sekunder yang dapat digunakan untuk keperluan menyusun karya ilmiah kemudian menganalisis faktor-faktor yang berhubungan dengan pokok-pokok permasalahan sehingga akan didapat suatu kebenaran atau data yang diinginkan. Dalam penyusunan penelitian ini penulis menggunakan metode deskriptif kuantitatif, karena penelitian yang dilakukan adalah penelitian yang menekankan analisisnya pada data-data numeric (angka).

Menurut Nazir (2005:39) menyatakan bahwa "penelitian deskriptif adalah metode dalam penelitian status kelompok manusia, suatu pemikiran, ataupun suatu kelas peristiwa 
KREATIF : Jurnal Ilmiah Prodi Manajemen Universitas Pamulang, Vol. 8, No.2, Desember 2020

pada masa sekarang yang bertujuan untuk membuat deskripsi, gambaran, atau lukisan secara sistematis, faktual dan akurat mengenai fakta-fakta, sifat-sifat serta hubungan antar fenomena yang diselidiki".

Sedangkan Arikunto (2012:65), menyatakan bahwa "penelitian kuantitatif memiliki kejelasan unsur yang rinci sejak awal, langkah penelitian yang sistematis, populasi, memiliki hipotesis jika perlu, memiliki desain jelas dengan langkah-langkah penelitian dan hasil yang diharapkan, memerlukan pengumpulan data yang dapat mewakili, serta ada analisa data yang dilakukan setelah semua data terkumpul."

\section{HASIL PENELITIAN DAN PEMBAHASAN}

Untuk mempermudah pembahasan atas analisis yang dilakukan, akan dijelaskan pengaruh dari masing-masing variabel bebas yang meliputi Kompensasi dan Motivasi Kerja terhadap Kinerja Guru.

Berikut tabel hasil uji reliabilitas penelitian ini:

\section{Tabel 1}

Hasil Uji Reliabilitas Data

\begin{tabular}{|l|l|l|l|}
\hline Variabel & Number of item & Cronbach Alpha & Kesimpulan \\
\hline Kompensasi (X1) & 11 & 0,612 & Reliable \\
\hline Motivasi kerja (X2) & 10 & 0,713 & Reliable \\
\hline Kinerja Guru (Y) & 10 & 0,773 & Reliable \\
\hline
\end{tabular}

Sumber: Data Primer diolah, 2017

Berdasarkan tabel di atas, variabel Kompensasi dengan nilai 0,612 adalah reliabel, variabel Motivasi Kerja dengan nilai 0,713 adalah reliabel dan Kinerja Guru 0,773 adalah reliabel, dapat disimpulkan bahwa 3 variabel yaitu Kompensasi, Motivasi Kerja dan Kinerja Guru adalah stabil dan konsisten.

Dengan kata lain bahwa seluruh pernyataan pada penelitian ini memiliki tingkat kehandalan yang baik dan dapat digunakan dalam analisis pada penelitian ini. Konsistensi yang dimaksud adalah dimana respoden menjawab keseluruhan pernyataan dengan baik tanpa kecacatan.

\section{Hasil Uji Asumsi Klasik}

Pada teknik analisis berganda maka digunakan uji asumsi klasik untuk memastikan bahwa pada model regresi tidak terjadi berbagai penyimpangan.

\section{a. Uji Normalitas}

Uji normalitas untuk mengetahui apakah data pada penelitian berdistribusi normal. Pada prinsipnya normalitas dapat dideteksi dengan melihat penyebaran data (titik) pada sumbu diagonal dari grafik atau dengan melihat histogram dari residualnya. Berikut hasil output uji normalitas pada gambar Normal Probability Plot of Regression Standarized Residual. 
KREATIF : Jurnal Ilmiah Prodi Manajemen Universitas Pamulang, Vol. 8, No.2, Desember 2020

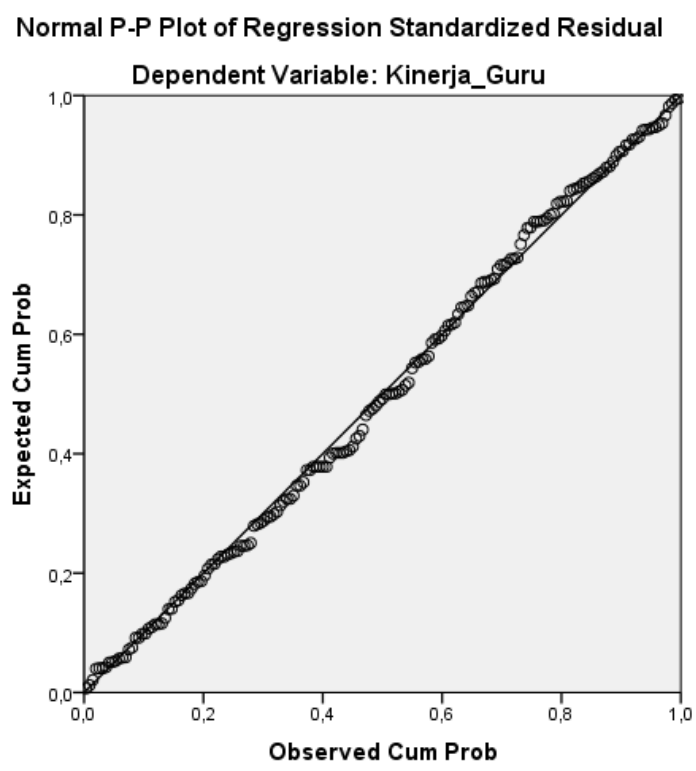

Sumber : Hasil Penelitian

Gambar 1 Uji Normalitas

Dapat dilihat dari grafik diatas bahwa pola penyebaran data dimana yang berbentuk titik atau lingkaran kecil menyebar disekitar garis dan mengikuti garis diagonal, dapat diartikan bahwa nilai residual yang dihasilkan dari regresi tersebut normal.

\section{b. Uji Multikolinieritas}

Uji Multikolonieritas bertujuan untuk menguji apakah model regresi ditemukan adanya korelasi antar variabel bebas (independen). Model regresi yang baik seharusnya tidak terjadi korelasi diantara variabel independen. Ghozali (2013: 103).Dasar pengambilan keputusan:

1) Jika nilai VIF < 10 maka tidak terjadi gejala multikolonieritas di antara variabel bebas.

2) Jika nilai VIF > 10 maka terjadi gejala multikolonieritas di antara variabel bebas.

Berikut hasil output uji multikolonieritas menggunakan SPSS pada tabel coefficients, sebagai berikut

Tabel 2

Uji Multikolinieritas - VIF (Variance Inflation factors)

Coefficients $^{\mathbf{a}}$

\begin{tabular}{|c|c|c|c|c|c|c|c|}
\hline \multirow[b]{2}{*}{ Model } & \multicolumn{2}{|c|}{$\begin{array}{l}\text { Unstandardized } \\
\text { Coefficients }\end{array}$} & \multirow{2}{*}{\begin{tabular}{|c|}
$\begin{array}{l}\text { Standardized } \\
\text { Coefficients }\end{array}$ \\
Beta
\end{tabular}} & & \multirow[b]{2}{*}{ Sig. } & \multicolumn{2}{|c|}{$\begin{array}{l}\text { Collinearity } \\
\text { Statistics }\end{array}$} \\
\hline & $\mathrm{B}$ & Std. Error & & & & Tolerance & VIF \\
\hline 1 (Constant) & 14,416 & 3,867 & & 3,728 &, 000 & & \\
\hline Kompensasi & ,198 & ,080 & ,173 & 2,475 & ,014 &, 850 & 1,176 \\
\hline $\begin{array}{l}\text { Motivasi_Ker } \\
\text { ja }\end{array}$ & ,438 & ,073 & ,419 & 5,989 &, 000 &, 850 & 1,176 \\
\hline
\end{tabular}

a. Dependent Variable: Kinerja_Guru

Sumber : Hasil Penelitian

Hasil perhitungan nilai tolerance menunjukan tidak ada variabel independen yang memiliki tolerance kurang dari 0,10 yang berarti tidk ada kolerasi atau hubungan antara 
KREATIF : Jurnal Ilmiah Prodi Manajemen Universitas Pamulang, Vol. 8, No.2, Desember 2020

variabel independent. Dari perhitungan nilai VIF juga menunjukan hal yang sama tidak ada satu variabel independen yang memiliki nilai VIF yang lebih dari 10,00 jadi dapat disimpulkan bahwa tidak terjadi multikolonieritas antara variabel independen dalam model regresi.

\section{c. Uji Heteroskedastisitas}

Pengujian ini bertujuan menguji apakah dalam model regresi terjadi ketidaksamaan variance dari residual satu pengamatan ke pengamatan yang lain. Jika variance dari residual suatu pengaatan ke pengamatan lain tetap, disebut homoskedastisitas, sedangkan untuk variance yang berbeda disebut heteroskedastisitas. Cara penentuan ada atau tidaknya heteroskedastisitas dapat dilihat dari grafik plot.

Scatterplot

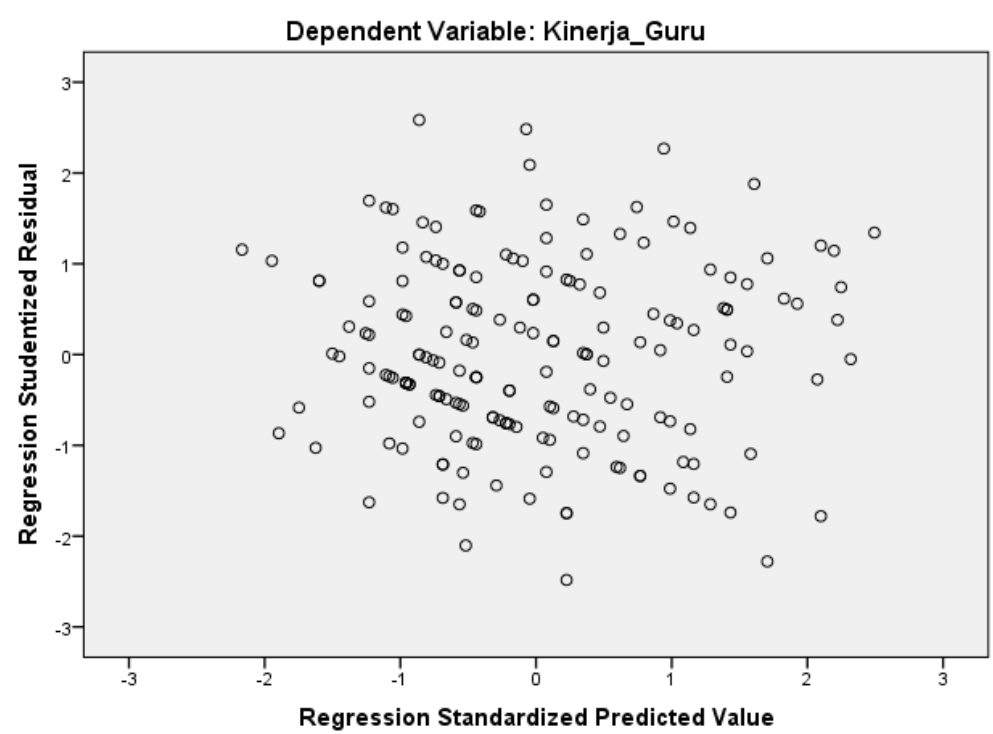

Sumber : Hasil Penelitian

Gambar 2 Scatterplot

Dari output di atas dapat diketahui bahwa titik-titk membentuk pola yang jelas, dan titik-titik menyebar di atas dan di bawah angka 0 pada sumbu Y. Jadi dapat disimpulkan bahwa tidak terjadi masalah heteroskedastisitas dalam model regresi, sehingga model regresi layak dipakai untuk memprediksi Kinerja Guru berdasarkan masukan dari Kompensasi dan Motivasi Kerja.

\section{Hasil Uji Hipotesis}

a. Pengaruh Kompensasi terhadap Kinerja Guru

Tabel 3

\section{Coefficients $^{\mathrm{a}}$}

Uji Parsial Variabel Kompensasi terhadap Kinerja Guru

\begin{tabular}{|c|c|c|c|c|c|}
\hline \multirow[b]{2}{*}{ Model } & \multicolumn{2}{|c|}{$\begin{array}{l}\text { Unstandardized } \\
\text { Coefficients }\end{array}$} & $\begin{array}{l}\text { Standardized } \\
\text { Coefficients }\end{array}$ & \multirow[b]{2}{*}{$\mathrm{t}$} & \multirow[b]{2}{*}{ Sig. } \\
\hline & $\mathrm{B}$ & Std. Error & Beta & & \\
\hline (Constant) & 24,144 & 3,840 & & 6,288 &, 000 \\
\hline $\begin{array}{c}\text { Kompensas } \\
\text { i }\end{array}$ & ,385 & ,081 & ,335 & 4,760 & ,000 \\
\hline
\end{tabular}


KREATIF : Jurnal Ilmiah Prodi Manajemen Universitas Pamulang, Vol. 8, No.2, Desember 2020

a. Dependent Variable: Kinerja Guru

Sumber: output SPSS 23

Hasil data rekapitulasi kuesioner dari 11 pernyataan yang berhubungan langsung dengan variabelKompensasi (X1) pada tabel 4.5, yakni secara keseluruhan semua pernyataan dalam variabel Kompensasi ini dapat diterima guru sebagai responden dengan pernyataan setuju dan sangat setuju sebesar $94,7 \%$.

Masing-masing pernyataan pada variabel Kompensasi (X1) dengan 11 butir pernyataan, seluruh item terbukti valid karena nilai $\mathbf{r}_{\text {hitung }}$ yang dihasilkan lebih besar dari pada nilai $r_{\text {tabel }}$ 0,146. Bahwa butir-butir pernyataan yang digunakan untuk mengukur variabel Kompensasi dapat dilanjutkan pada pengujian selanjutnya.

Hasil uji parsial (uji t) yang ditampilkan pada tabel 4.15 di atas menunjukkan nilai $t_{\text {hitung }}$ yang dihasilkan oleh variabel kompensasi sebesar 4,760 dengan tingkat signifikansi $0,000<0,05$. Dengan demikian Ho ditolak dan H1 diterima, yang berarti variabel kompensasi secara individu atau parsial mempengaruhi variabel kinerja guru secara signifikan.

Nilai $t_{\text {hitung }}$ variabel kompensasi yang bernilai positif sebesar 4,760 menunjukkan terdapat hubungan positif atau searah antara kompensasi dengan kinerja guru. Artinya, semakin tinggi kompensasi maka semakin tinggi pula kinerjanya.

\section{b. Pengaruh Motivasi Kerja terhadap Kinerja Guru}

Tabel 4

Uji Parsial Variabel Motivasi Kerja terhadap

Kinerja Guru

Coefficients $^{\text {a }}$

\begin{tabular}{|c|c|c|c|c|c|c|}
\hline & \multirow[b]{2}{*}{ Model } & \multicolumn{2}{|c|}{$\begin{array}{c}\text { Unstandardized } \\
\text { Coefficients }\end{array}$} & $\begin{array}{l}\text { Standardized } \\
\text { Coefficients }\end{array}$ & \multirow[b]{2}{*}{$\mathrm{T}$} & \multirow[b]{2}{*}{ Sig. } \\
\hline & & B & Std. Error & Beta & & \\
\hline 1 & (Constant) & 20,836 & 2,909 & & 7,163 &, 000 \\
\hline & $\begin{array}{c}\text { Motivasi } \\
\text { Kerja }\end{array}$ & ,508 & ,068 & ,485 & 7,430 & ,000 \\
\hline
\end{tabular}

a. Dependent Variable: Kinerja Guru

Sumber: output SPSS 23

Hasil data rekapitulasi kuesioner dari 10 pernyataan yang berhubungan langsung dengan variabel motivasi kerja (X2) pada tabel 4.6, yakni secara keseluruhan semua pernyataan dalam variabel motivasi kerja ini dapat diterima guru sebagai responden dengan pernyataan setuju dan sangat setuju sebesar 93,4\%.

Masing-masing pernyataan pada variabel motivasi kerja (X2) dengan 10 butir pernyataan, seluruh item terbukti valid karena nilai $\boldsymbol{r}_{\text {hitung }}$ yang dihasilkan lebih besar dari pada nilai $r_{\text {tabel }} 0,146$. Bahwa butir-butir pernyataan yang digunakan untuk mengukur variabel motivasi kerja dapat dilanjutkan pada pengujian selanjutnya.

Hasil uji parsial (uji t) yang ditampilkan pada tabel 4.16 di atas menunjukkan nilai $t_{\text {hitung }}$ yang dihasilkan oleh variabel motivasi kerja sebesar 7,430 dengan tingkat signifikansi $0,000<0,05$. Dengan demikian Ho ditolak dan H2 diterima, yang berarti variabel motivasi kerja secara individu atau parsial mempengaruhi variabel kinerja guru secara signifikan. 
KREATIF : Jurnal Ilmiah Prodi Manajemen Universitas Pamulang, Vol. 8, No.2, Desember 2020

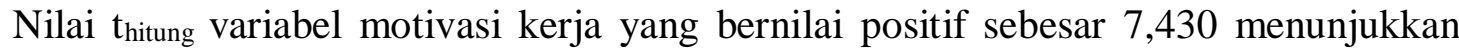
terdapat hubungan positif atau searah antara motivasi kerja dengan kinerja guru. Artinya, semakin tinggi motivasi kerja maka semakin tinggi pula kinerjanya.

\section{Pengaruh Kompensasi dan Motivasi Kerja terhadap Kinerja Guru}

\section{Tabel 5}

Uji Simultan (F)

ANOVA $^{\mathbf{a}}$

\begin{tabular}{|cc|c|c|c|c|c|}
\hline & & Sum of & & & \\
& Model & Squares & Df & Mean Square & F & Sig. \\
\hline 1 & Regression & 468,224 & 2 & 234,112 & 31,452 &, $000^{\mathrm{b}}$ \\
& Residual & 1324,925 & 178 & 7,443 & & \\
& Total & 1793,149 & 180 & & & \\
\hline
\end{tabular}

a. Dependent Variable: Kinerja Guru

b. Predictors: (Constant), Motivasi Kerja, Kompensasi

Hasil data rekapitulasi kuesioner dari 10 pernyataan yang berhubungan langsung dengan variabel Kinerja Guru (Y) pada tabel 4.7, yakni secara keseluruhan semua pernyataan dalam variabel kinerja guru ini dapat diterima guru sebagai responden dengan pernyataan setuju dan sangat setuju sebesar $93,5 \%$.

Masing-masing pernyataan pada variabel Kinerja Guru (Y) dengan 10 butir pernyataan, seluruh item terbukti valid karena nilai $\boldsymbol{r}_{\text {hitung }}$ yang dihasilkan lebih besar dari pada nilai $r_{\text {tabel }} 0,146$. Bahwa butir-butir pernyataan yang digunakan untuk mengukur variabel Kinerja Guru dapat dilanjutkan pada pengujian selanjutnya.

Hasil uji simultan (uji F) yang ditampilkan pada tabel 4.16 di atas menunjukkan nilai $\mathrm{f}_{\text {hitung }}$ yang dihasilkan sebesar 31,452 $>\mathrm{f}_{\text {tabel }}$ 3,05 dengan tingkat signifikansi 0,000 $<0,05$. Dengan demikian H3 diterima, yang berarti variabel kompensai dan motivasi kerja secara simultan atau bersama-sama mempengaruhi variabel kinerja guru secara signifikan.

\section{Tabel 6}

\section{Uji Koefiensi Determinasi Kompensasi dan Motivasi Kerja terhadap Kinerja Guru} Model Summary ${ }^{b}$

\begin{tabular}{|c|c|c|c|c|c|}
\hline Model & $\mathrm{R}$ & $\mathrm{R}$ Square & $\begin{array}{c}\text { Adjusted R } \\
\text { Square }\end{array}$ & $\begin{array}{c}\text { Std. Error of } \\
\text { the Estimate }\end{array}$ & $\begin{array}{c}\text { Durbin- } \\
\text { Watson }\end{array}$ \\
\hline 1 &, $511^{\mathrm{a}}$ &, 261 &, 253 & 2,72826 & 2,012 \\
\hline
\end{tabular}

a. Predictors: (Constant), Motivasi_Kerja, Kompensasi

b. Dependent Variable: Kinerja_Guru

Sumber: output SPSS 23

Berdasarkan uji Koefiensi Determinasi R ${ }^{2}$. Nilai Koefisien Determinasi Adjusted R Square sebesar 0.253. Data tersebut mengindikasikan bahwa Kompensasi dan Motivasi Kerja terhadap Kinerja Guru menberikan kontribusi sebesar 25,3\% sisanya sebesar 74,7\% dijelaskan oleh variabel lain diluar penelitian ini. Menurut Johanes Supranto (2001:127) dapat dilihat pada tabel 3.6 dengan tingkat pengaruh $25 \%$ maka data tersebut dinyatakan berpengaruh cukup kuat. 
KREATIF : Jurnal Ilmiah Prodi Manajemen Universitas Pamulang, Vol. 8, No.2, Desember 2020

\section{KESIMPULAN DAN SARAN}

\section{A. Kesimpulan}

Berdasarkan hasil analisis dan pembahasan maka penelitian ini dapat disimpulkan sebagai berikut :

1. Pengaruh Kompensasi terhadap Kinerja Guru PNS SD Negeri Kecamatan Pamulang: Berdasarkan perhitungan diketahui secara parsial variabel kompensasi berpengaruh terhadap kinerja guru, dimana $\mathrm{t}$ hitung sebesar 4,760 lebih besar dari $\mathrm{t}$ tabel pada $\alpha=0,05$ yaitu 1,973. Dengan demikian Ho yang menyatakan bahwa kompensasi tidak berpengaruh signifikan terhadap kinerja guru ditolak, berarti $\mathrm{H} 1$ yang menyatakan kompensasi berpengaruh signifikan terhadap kinerja guru diterima. Dengan demikian dapat disimpulkan bahwa kompensasi berpengaruh positif terhadap kinerja guru PNS SD Negeri Kecamatan Pamulang.

2. Pengaruh Motivasi Kerja terhadap Kinerja Guru PNS SD Negeri Kecamatan Pamulang : Berdasarkan perhitungan diketahui secara parsial variabel motivasi kerja berpengaruh terhadap kinerja guru, dimana $t$ hitung sebesar 7,430 lebih besar dari $t$ tabel pada $\alpha=0,05$ yaitu 1,973 . Dengan demikian Ho yang menyatakan bahwa motivasi kerja tidak berpengaruh signifikan terhadap kinerja guru ditolak, berarti H2 yang menyatakan motivasi kerja berpengaruh signifikan terhadap kinerja guru diterima. Dengan demikian dapat disimpulkan bahwa motivasi kerja berpengaruh positif terhadap kinerja guru PNS SD Negeri Kecamatan Pamulang.

3. Pengaruh Kompensasi dan Motivasi Kerja terhadap Kinerja Guru PNS SD Negeri Kecamatan Pamulang: Sebelumnya telah dijelaskan melalui metode kuantitatif linier berganda telah terbukti bahwa kompensasi dan motivasi kerja secara bersama-sama memiliki pengaruh yang signifikan terhadap kinerja guru. Hal ini ditujukkan oleh hasil analisis regresi linier berganda signifikan dengan nilai $\mathrm{F}$ hitung sebesar 31,452 dengan tingkat signifikansi 0,000 . Nilai signifikansi tersebut masih berada di bawah nilai signifikansi yang ditetapkan yaitu 0,05 dan positif, sehingga dapat disimpulkan bahwa kompensasi dan motivasi kerja berpengaruh signifikan terhadap kinerja guru PNS SD Negeri Kecamatan Pamulang.

\section{B. Saran}

Berdasarkan kesimpulan di atas dan pengelolaan hasil kuesioner di masing-masing variabel yang memiliki nilai/skor terendah, maka dapat disampaikan saran-saran sebagai bahan pertimbangan pihak manajemen sebagai berikut:

1. Diharapkan kepada pihak sekolah agar menjadi perhatian dan pertimbangan terkait kesejahteraan guru, yang dinilai berdasarkan kinerja masing-masing guru, agar dapat berdampak terhadap kinerja dan semangat guru dalam melaksanakan tugasnya.

2. Disarankan kepada pihak sekolah agar setiap tiga bulan sekali setiap guru dapat diberikan pendidikan dan pelatihan mengenai bagaimana cara mengajar yang baik dan tidak membosankan bagi anak-anak.

3. Diharapkan kepada pihak sekolah agar dapat dipertegas mengenai disiplin jam kerja, apabila terdapat guru yang terlambat agar dikenakan pemotongan tambahan penghasilan PNS (TPP) dan pengurangan nilai sasaran kinerja pegawai (SKP), dan apabila melebihi jam kerja dapat diberikan penilaian lebih di dalam SKPnya serta mendapatkan uang lemburan, agar setiap guru bersemangat dalam melaksanakan tugasnya. 
KREATIF : Jurnal Ilmiah Prodi Manajemen Universitas Pamulang, Vol. 8, No.2, Desember 2020

\section{DAFTAR PUSTAKA}

Arikunto, Suharsimi, 2012, Prosedur Penelitian Suatu Pendekatan Praktek, Rineka Cipta, Jakarta.

Arianto, Nurmin 2020. Kepemimpinan dan Komunikasi Pengaruh nya Terhadap KEPUASAN Kerja Sebagai Variabel Intervening. Jurnal Ilmiah Kreatif Prodi Manajemen. Vol. 8 No 1, Hal 124-137.

Arianto, Nurmin dan Hadi Kurniawan. 2020. Pengaruh Motivasi dan Lingkungan Kerja terhadap Kinerja karyawan. Jurnal Ilmiah Manajemen Sumber Daya Manusia, JENIUS Vol. 3 No. 3, Mei 2020.

Darma, Surya, 2008, Penilaian Kinerja Guru, Direktur Tenaga Kependidikan, Ditjen PMPTK, Jakarta

Farihah, Ipah. 2006. Buku Panduan Penelitian UIN Syarif Hidayatullah Jakarta. UIN Prees. Jakarta.

Ghozali, Imam. 2013. Aplikasi Analisis Multivariete Dengan Program Ibm Spss 23. Badan Penerbitan UNDIP. Semarang.

Hamali, Arif Yusuf. 2016. Pemahaman Manajemen Sumber Daya Manusia. CAPS. Yogyakarta.

Hasibuan, Melayu S.P. 2007. Manajemen Sumber Daya Manusia. PT Bumi Aksara. Jakarta, cet. 10.

Kadarisman, M. 2012. Manajemen Kompensasi. Raja Grafindo Persada. Jakarta.

Mangkunegara, Anwar Prabu. 2009. Manajemen Sumber Daya Manusia Perusahaan. PT. Remaja Rosdakarya. Bandung.

Mulyasa. 2013. Uji Kompetensi dan Penilaian Kinerja Guru. Remaja Posdakarya. Bandung.

Nazir, Mohammad, 2005, Metode Penelitian, Ghalia Indonesia. Jakarta

Sagala, Syaiful. 2010. Manajemen Strategik Dalam Peningkatan Mutu Pendidikan. Alfabeta. Bandung, cet 4.

Sedarmayanti dan Syarifudin Hidayat. 2011. Metodologi Penelitian. CV. Mandar Maju. Bandung.

Sugiyono. 2011. Metode Penelitian Kuntitatif Kualitatif Dan R\&D. Alfabeta

Sulistiyani, Ambar Teguh, dan Rosidah. 2009. Manajemen Sumber Daya Manusia, Konsep, Teori Dan Pengembangan Dalam Konteks Organisasi Publik. Graha Ilmu. Yogyakarta. Cet 1.

Supardi. 2013. Kinerja Guru. Rajawali Pers. Jakarta.

Tabrani, Rusyan. 2000. Upaya Meningkatkan Budaya Kinerja Guru. CV Dinamika Karya Cipta. Cianjur.

Umar, Husein. 2005. Riset Sumber Daya Manusia Dalam Organisasi. PT. Gramedia Pustaka Utama., Jakarta.

Yani, M. 2012. Manajemen Sumber Daya Manusia. Mitra wacana media.

Zainal, Veithzal Rivai, 2014. Manajemen Sumber Daya Manusia Untuk Perusahaan. Rajawali Pers. Jakarta. 